\title{
Museum pedagogy and the evocation of moments of responsibility
}

KATRINE TINNING*

\begin{abstract}
"If [...] cultural criticism has a task at the present moment, it is no doubt to return us to the human where we do not expect to find it, in its frailty and at the limits of its capacity to make sense."
\end{abstract}

(Butler 2006:151)

\begin{abstract}
In 2010-11, an exhibition entitled It's not Your Fault! was on display at The Women's Museum in Denmark. The museum aimed to contribute to the prevention of rape by giving young people, who were the target group, a sense of shared responsibility for the prevention of rape. In this article, the museum's hopes regarding the prevention of rape are read as a hope of deepening of responsibility. The exhibition is approached as a conglomerate of didactic materials and contents that may encourage visitors to engage in educational relations with the museum regarding traumatic events of sexual violence. The potential of the design and dramaturgy of the exhibition to evoke moments of ethical responsibility is explored. Inspired by Emmanuel Lévinas, the article discusses the joint emergence of learning and responsibility, and approaches ethical responsibility in the double sense of response and care. This particular point in grounding ethics in education is discussed in relation to central features of the exhibition. It is suggested that such features, like the poetic re-interpretations in the exhibition, have the potential of meeting and unsettling the visitor and lay the grounds for ethical responsibility and for critical re-thinking. However, it is also discussed how the exhibition represents controversial issues in regard to displaying the subject.
\end{abstract}

Key words: Museum education, difficult exhibitions, sexual violence, responsibility, learning, sensibility. 
68 Can exhibitions in museums of cultural history encourage young people to become ethically involved in controversial issues and difficult heritage? What is the role of poetic or artistic re-interpretations of lived experiences with violence in appealing to visitors' sense of responsibility? These are the fundamental questions addressed in the following discussion of an exhibition for young people entitled It's not Your Fault! (Det er ikke din skyld!) displayed at The Women's Museum, (Kvindemuseet) in Aarhus, Denmark, in 2010-11.

The exhibition was placed up under the roof of the museum, and to get to the exhibition area you had to climb a narrow staircase. Entering, you would be standing in a large room crisscrossed by collar beams from ceiling to floor, which gave the room a rough look. Here, you were met by human faces on a video screen that occupied a considerable space of one of the white walls. The spatial arrangement was like an agora in which visitors could move around, and the video screen served as the visual and auditive axis around which the rest of the exhibition evolved. In front of the screen were huge letters - the letters corresponding to F., A., U., L. and T. in Danish - in different colours lying on the floor, overturned. On a table with chairs was a TV where you could turn on a movie about a young boy being sexual abused by his football coach. At the back of the room was a workshop: scissors and paper were placed on a table, and visitors were encouraged to create their own words and expressions - both those with meaning and nonsense - and paste them on a nearby wall, where other visitors could come and look at them. A tiny door in a white wall with letters on it led into a small hidden room, which was set up like a "kids' bedroom". Here, a little bedside lamp had fallen onto the floor.
In the exhibition, the cultural histories, collective memories and personal narratives about rape were displayed in artistic or poetic interpretations, but also in more realistic ways. Close to the entrance of the exhibition, visitors were met by informative posters with pictures and texts explaining general aspects of the cultural history of rape. In this way, the exhibition provided cognitive knowledge-based mediation of cultural or collective memories and discourses on rape, which interacted with the poetic installations. Brochures were also available on a table in the exhibition offering pragmatic information about "what to do" in situations of sexual violence. In the following discussion, the focus is on the artistic reinterpretations and the presentation of personal life stories in the exhibition. It explores how a critical exhibition such as It's not Your Fault! about a difficult subject matter like rape can be said to work in order to produce sensory (emotional and bodily) experiences that may stimulate a young audience to critical engagement and reflection.

The Women's Museum is a politically involved institution that wishes to bring women's conditions of life into debate. It was founded in the mid-1980s and recognised by the Danish state as a special mandate museum in 1991. The museum maintains a practice of reaching out to women in need of a helping hand, offering them different kinds of employment in the institution. The aim of the museum is to conduct research, build collections and spread knowledge about women's lives and work as part of Danish cultural history.

During the last 15 years, in the wave of so-called "new museology", the role of museum institutions as agents of change in contemporary society has met with great 


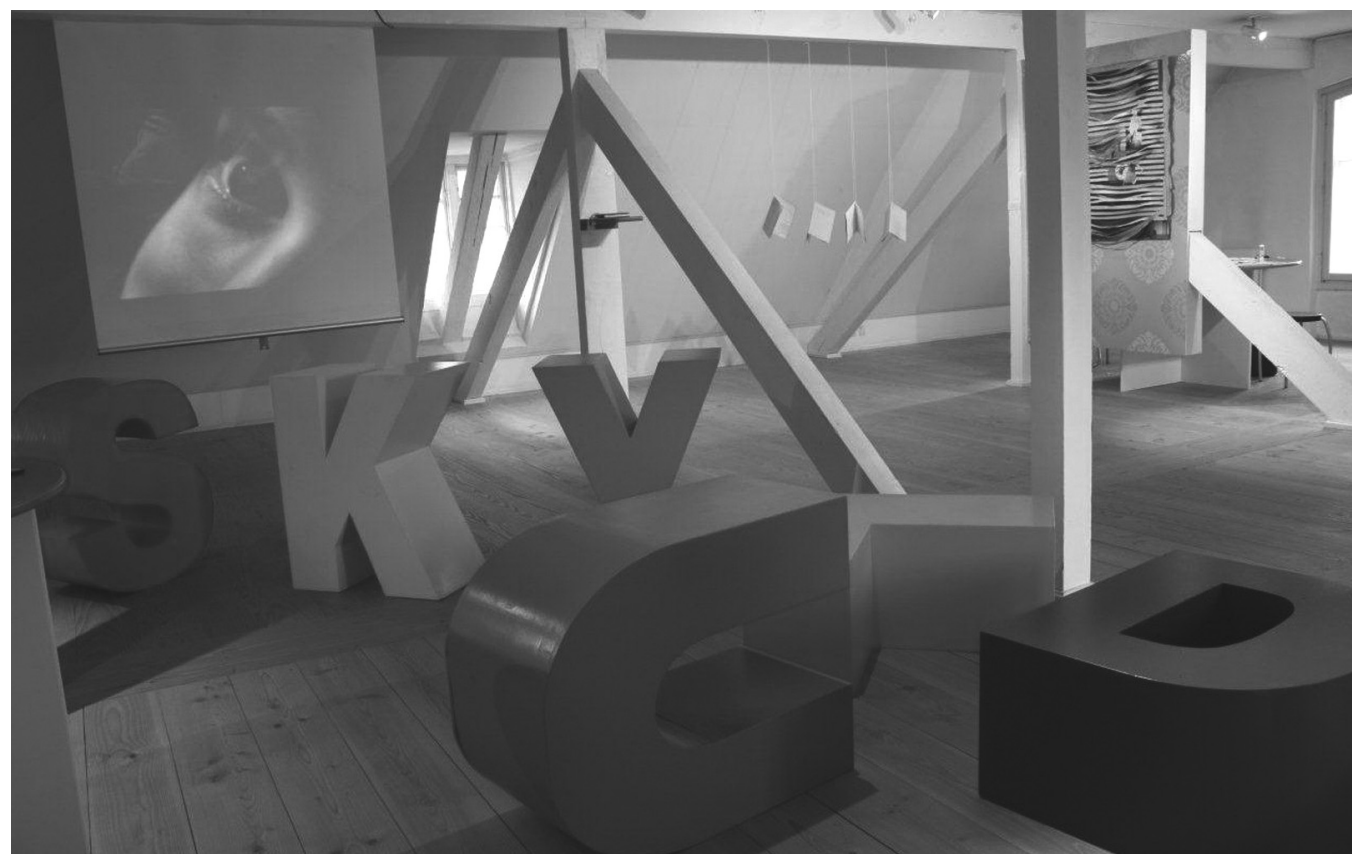

Fig. 1. Scenery from the exhibition entitled It's not Your Fault shown at The Women's Museum in Aarhus, Denmark 2010-11. Photo: The Women's Museum.

interest. The question of the social responsibility of museums has been raised, and attention has been paid to the ways museums communicate with their audience, how they work with inclusion, representation and participation, e.g. how some things are shown while others are left out, and how some people are invited, while others are marginalised (Sandell 2003, 2007, 2011, Janes 2007, 2009, Goodnow \& Akman 2008, Marstine 2011 for example). Parallel to these discussions, it has been discussed whether and how museums can contribute to life-long learning (see for example Hein 1998, Hooper-Greenhill 2000, 2004). Lately, focus in the field of museology has been on the involvement of museums with hot or controversial topics of different kinds (Silvén \&
Björklund 2006, Cameron \& Kelly 2010), and the creation of visitors' critical engagement (see for example Witcomb 2010, 2013).

In this context, the exhibition entitled It's not Your Fault! is interesting, because it was created as an attempt made by the museum to contribute to visitors' learning and assuming of responsibility by presenting an exhibition on a theme that otherwise often tends to be excluded or marginalised from discourse. Raising the issue of rape can be linked to the current interest within the museum world to address the more difficult, controversial and darker or taboo-laden aspects of heritage and human life.

In the following, it is suggested that the exhibition - as a conglomerate of didactic 
70 materials and contents - can be seen as an attempt to evoke educational relations between the museum and its visitors regarding traumatic events of sexual violence. The potential of the exhibition design and dramaturgy to evoke moments of ethical responsibility for other human beings and our interpersonal relations is discussed.

The museum's explicit educational intention with putting on this exhibition was to create a change in society, and to contribute to the prevention of rape by offering young visitors the opportunity to share in a sense of responsibility for rape taking place in society (Ipsen 2010). The museum also hoped that the exhibition would help puncture myths about rape by inviting the young audience to reflect critically on rape, victims, perpetrators and their own attitudes to rape, and to stimulate such a sense of involvement by drawing attention to the complex problems involved (Ipsen 2010). In this sense, the exhibition is a political act aiming at social change. The aim of the museum - to contribute to the prevention of suffering - can be associated with the attempts made by Holocaust memorial museums to "mobilize visitors as both historical witnesses and agents of present and future political vigilance" (Williams 2011:220).

In this article, the intention is to discuss some basic premises for a critical exhibition pedagogy that intends to encourage ethical involvement by teaching a difficult subject matter. The exhibition in the Women's Museum is used as a case for this discussion. The article sets out to "read" the exhibition through the lens of Emmanuel Lévinas' definition of ethics as being-for-the-other (1993, 2008, 2009). With his central concept of the face, Lévinas offers a perspective on responsibility that can be used to explore the teaching of ethics in this exhibition specifically, and the conditions of teaching ethics in museums more generally. In addition, the exhibition will be discussed in relation to Judith Butler's (2006) concept of effacing, which is helpful in showing what happens when you teach ethics, but wipe out certain faces. Furthermore, the exhibition is related to Sharon Todd's $(2003,2008)$ idea of the importance of listening, which can contribute to an understanding of the potential of artistic re-interpretation to evoke responsibility. This article does not set out to provide a traditional exhibition critique, but will use the exhibition as an occasion for discussing how ethics, in Lévinas' sense of the term, can be achieved in an exhibition setting.

From this perspective, it is argued that teaching ethics in the museum exhibition must be based on evoking moments of being-forthe-other, which are the grounding moments of responsibility. These moments are welcomings of the other as being different from one self. It is argued that teaching ethics in the museum is tied to a re-thinking of prevailing discourse and praxis, and to a re-creation of the sense one has of self, others and relations. The museum exhibition must offer a zone for visitors to approach the other as being different or radically other, because this is the condition of possibility for critique i.e. critical re-thinking of personal and collective experiences and memories.

\section{BEING-FOR-THE-OTHER}

Emmanuel Lévinas provides a theoretical framework for discussing educational relations between the visitor and the exhibition in the perspective of ethics of responsibility (1993, 
2008, 2009). To Lévinas, the foundation of ethics consists of the obligation to welcome. This means showing responsibility in the double sense of the word - to respond to and be responsible for the other (autrui), the neighbour, which he calls face. Face is important, because our unique humanity is expressed in our faces. Face is also an important metaphor and, as Mieke Bal (2009:19) draws attention to, in our everyday language "to face" is both the act of looking someone else in the face, to come to terms with something that is difficult to live with by facing it (instead of denying or repressing it), and making contact. Jacques Derrida (1997) describes this foundation of ethics as the onefor-the-other, or hospitality.

Following Lévinas, it is the relation to the other which is fundamental: "the relationship to the other man seemed to me to be the definition, the main feature, the grand mystery, if you will, of humanity and even man [...] what we call transcendence, the exit from oneself. Is the human. And this exit from oneself is always the relationship we have with the other man" (Lévinas in an interview with Michel Fields, Ina.france on 29 June 1993). To Lévinas, it is the relation to the other that gives meaning to everything.

Learning from the other must be approached as a sensory experience, which transforms subjectivity. It is a continual transgression of subjectivity towards the other, the beyond or elsewhere. This understanding entails a definition of learning as being transformative; the sense one has of oneself, the other and one's relations are re-created. Following Lévinas, it is through the responsibility for the other that the visitor can be critical: it is from the being-for-the-other, the "il $y a$ " (which here can be understood as here $I \mathrm{am}$ ) said to the neighbour, that the visitor can come to see the limitations of his/her own world and can recognise that things could be different and otherwise, and thus engage in critique as a critical and creative re-saying of current conditions.

As is important to the understanding of museum education on responsibility, Lévinas establishes a link between ethics and learning. As the philosopher and educator Sharon Todd (2008:171) maintains: "What is truly extraordinary about his ethics, and consequently what is highly relevant for readers in the field of education, is that this ethical welcoming takes on the characteristics of a pedagogical relation. Lévinas describes welcoming of the Other as the Self's capacity to learn from the Other as the teacher. At the core of his philosophy, then, lies a theory of learning one that is not so much concerned with how the subject learns content, but with how the subject learns through a specific orientation to the Other." In this perspective, learning about cultural heritage in the museum exhibition will imply being-for a difficult heritage, and experiencing this heritage not as a settled matter, not as something to gain certain knowledge of in the first place, but as a relation of caring, which is a tenderness to the other, a being touched by otherness. Learning, then, is to engage with the heterogeneity of cultural history.

\section{FACE-TO-FACE}

In the exhibition entitled It's not Your Fault!, the cultural history of sexual violence was rendered by human faces telling their different personal narratives in a movie shown on a large screen in the centre of the room. In this zone of the exhibition, the visitor was offered 
72 the possibility of face-to-face meetings with victims' stories. The installation raised questions as to whether this method of teaching ethics in the exhibition was purposeful in relation to representing sexual violence and inviting visitors to face-to-face meetings, which could encourage respons-ibility.

The large video screen in the exhibition room acted as a cinematic presentation of close-ups of different human faces, which in turn told personal life stories about experiences with rape. Here, cultural history of sexual violence was expressed as a multiplicity of micro-narratives. This was in line with the general approach of the exhibition, i.e. not primarily to display rape in terms of sexual violence taking place in relation to war or other exceptional events in macro-perspective, but in relation to rape as a watershed event for human beings as they go on living their relations to others.

The video screen offered openings of spaces for face-to-face meetings or proximity to unique (individual and singular) faces. Bonnell \& Simon's (2007:78) research on exhibition practice from a Lévinasian perspective shows that the specificity or uniqueness, and the detail of certain objects within the mise-en-scène of an exhibition, can invite visitors into a space where proximity to the face of the other becomes possible.

According to Lévinas (2009:91), "face is a trace of itself, given over to my responsibility, but to which I am wanting and faulty. It is as though I were responsible for his morality, and guilty of surviving. A face is a straightforward immediacy more tense than that of an image offered in the straightforwardness of an intuitive intention". The educational relation of face-to-face "works" in a pedagogical and ethical sense, not due to intentionality, but to its "immediacy" or its invitation to care and to question oneself and one's relations: "We name this calling into question of my spontaneity, by the presence of the Other, ethics" (Lévinas 2008:43). The difficulties of dealing with ethics in a museum exhibition, in the perspective of Lévinas, consist in the fact that in the moment face shows itself, one is confronted with one's own limitations and insufficiency to care adequately.

Lévinas maintains that proximity is not a state, but rather a restlessness with regard to faces' expressions of "Thou shalt not kill": do not commit violence (2009:82). The video screen with the faces had the potential to work as an invitation to the visitor to engage in relations of proximity to an otherness not necessarily conforming to existing norms or possibly to control. Teaching in the exhibition in this way could create movements towards the other by evoking both wondering (being receptive to), and wandering (breaking up from one's home). This could entail sensory transformative learning from the other, not as a stable or settled matter, but rather as a nomadic being-for.

The museum had chosen to let actors perform the narratives of sexual violence experienced by the "real" victims. This was to give the victims privacy and minimise any risk of harrassment. However, the concern regarding privacy for victims also posed constraints on the exhibition. One could ask whether letting actors play victims might contribute to the marginalisation of victims and categorisations of them as "outsiders", because their real faces were not included in public space and not presented in the collective and cultural history on display?

The philosopher and gender theorist Judith Butler, re-thinking Lévinas in relation to post- 
9/11 America, is helpful in understanding how a face can be "that for which no words really work [...] the face seems a kind of a sound" (Butler 2006:134). Butler draws attention to how expressions other than sonorous vocalisations seem to be figurable as face, such as the human body - the craning of the neck, the raising of the shoulder blades can "cry", "sob" or "scream" (Butler 2006:133, 144). But - basically - what is human is not represented by faces in exhibitions: "representation must not only fail, but must show its failure. There is something unrepresentable that we nevertheless seek to represent, and that paradox must be retained in the representations we give" (Butler 2006:144). In the exhibition entitled It's not Your Fault, this becomes apparent when we notice that the faces on the screen are not "really there", but are mediated by video and performed by actors: this even troubles our ideas of appearance, here and now, and of truth. Revealing the "failure" in different ways of representing "reality" or "truth" further suggests that even one's self-representations could be failures. One can only see one's own face in a mirror as a representation, not as reality or truth.

Most importantly, it is when the exhibition reveals this fundamental failure to represent the other that teaching comes to offer important gifts of revealing how we are cut through by otherness, always failing to arrive at the right time and place. How faces fail to represent, but also how this failure or shortcoming can point to the elsewhere is what Butler maintains, when she talks about pictures of burning children from the Vietnam War and how they "[d]espite their graphic effectivity [...] pointed somewhere else, beyond themselves, to a life and to a precariousness that they could not show" (Butler 2006:150).

However, the exhibition does not only abstain from showing victims - perpetrators' faces are also left out. Butler, concerning herself with the framing of face in media, also talks about a kind of absence, which she terms effacement; effacement happens through occlusion or through representation itself (2006:147). In the exhibition, a form of effacement takes place as the faces of perpetrators are not shown. Despite their facelessness, these are endowed with the intimating power of face to demand an ethical response, appearing as traces of themselves, almost clandestine. Following Butler "[c]ertain faces must be admitted into public view, must be seen and heard for some keener sense of the value of life, all life, to take hold" (2006:xviii). This is an argument against the choice by the museum not to represent the perpetrators - to prevent violence of rape, and deepen responsibility among humans, care must count for all humans. Given that the founding moment of ethics happens otherwise than consciousness or knowledge, hospitality to the other as otherwise than already categorised seems indispensable, but nevertheless highly controversial. The dilemma is that a totalisation of face occurs in the act of already beforehand defining the "perpetrator" as persona non grata. On the other hand, one can ask whether showing the faces of perpetrators to visitors, who may be victims of rape, is caring for the vulnerable other - i.e. care as Lévinas explains it?

\section{PoETIC SAYING}

While the exhibition primarily unfolded in one large room, one could also enter a tiny 
74 space through a small, almost hidden, doorway cut out in a wall on which letters were written in ways that made them vibrate between visible and invisible, between sense and non-sense, illustrating how words can express, fail to catch and evade the meaning of an experience. In the tiny room, there was a rather small bed and a bedside lamp that had been knocked to the floor, the walls were sloping and the room was dimly lit. The atmosphere was claustrophobic and unheimlich. You immediately got the feeling that this could have been the scene of very unpleasant events.

In his second major work Otherwise than Being or Beyond Essence (2009), Lévinas splits up the concept of face, or develops it further, into the conceptualisation of saying-said - a distinction that is useful in understanding expression or response in museum teaching. While the said is the already conceptualised expression, appearing as a theme or category in the prevailing discourse, saying is expression tied to the infinitely other. Saying cannot be reached by consciousness or grasped by already established rationalities. In contrast to said, saying is what troubles or destabilises the said. However, both the said and saying are of basic importance to the existence of society, justice and thinking. They are bound together in an intricate tension: the said keepis a trace of saying and expresses the meaning of being, and saying is a kind of communication of meaning - not primarily as a mode of cognition, however, but rather as sensible exposure. Saying as a way of welcoming the other as radical other, different from the same, is a way of being for the other, which conditions critique.

If we look at the teaching of ethics from this perspective, the exhibition has the potential to encourage visitors' ethical engagement in rape as a difficult heritage, because it offers poetic or artistic re-interpretations of sexual violence. The letters on the wall and the "kids' bedroom", for example, were expressions tht retained traces of otherness, and they worked as a saying on the verge of sense and nonsense. These installations highlighted the difficulties inherited in expressing the other as wholly otherwise, and they had the potential for inducing a breaking-off from inwardness by pointing to the shortcomings, what is left out, which could remind visitors that things could be said differently.

The huge letters spelling S.K.Y.L.D. (Danish for F.A.U.L.T.), thrown pell-mell onto the floor in the large room in front of the video screen with faces, were threedimensional in order to allow visitors to sit on them, put on headphones and listen to victims' narratives. The difficult and emotionally unsettling content of the stories told in the headphones were mirrored by the constellation of the letters. The letters, like metaphorical and mythical images of chaos, the pell-mell and the un-formed, also conveyed a picture of a world out of (normal) order and control, and "dragged" visitors into a borderland between known and alien. The letters had the potential for inviting visitors to a sensible relation to the other and for calling attention to the zones of the chaotic, which constitute the margins of and the holes in our everyday discourse.

To sum up, from the perspective of Lévinas, teaching ethics in the exhibition entails a risk, because visitors as others cannot be controlled by the museum. This also means that there are no guarantees that visitors will not experience the display in ways that differ from the museum's intention- for example that that 
some visitors would feel aroused or even be inspired to commit rape by visiting the exhibition. Furthermore, the sensible ways of appealing to proximity to face involving visitors' vulnerability or tenderness for the other might be considered too provocative for some people. This could be the case for visitors who have themselves experienced sexual violence, which raises the difficult question of how the exhibition can welcome victims as unique visitors. Finally, the museum's arguments for displaying rape may collide with parents' or teachers' ideas of education of youngsters.

\section{RECEIVING A DIFFICULT GIFT}

By performing in unexpected, nonconventional and artistic forms, the exhibition asked visitors to re-conceptualise themselves, see faces in different ways, do an "about-face". In this way museum teaching has the possibility of becoming an event, which, as Simon (2005:7) writes, is "a moment in which learning is not simply the acquisition of new information but an acceptance of another's testamentary address as a possible inheritance, a difficult 'gift' that in its demand for a non-indifference, may open questions, interrupt conventions, and set thought to work through the inadequate character of the terms on which I grasp myself and my world“. On these terms teaching and learning in the museum are not so much about content, but more about receiving others and being susceptible to difficult recollections. The museum exhibition could then become a place for welcoming questions of relationality, and create moments of radical questioning and learning about the possibilities for responsibility. Learning about cultural history can thus become a transformative process.

Sharon Todd (2003:117 ff.), inspired by Lévinas, raises the pivotal question of whether we always have to act? She discusses how listening and passivity are ways of being susceptible to the other in educational relations, but also how this aspect is underdeveloped in contemporary pedagogy, where the focus is on the active, "doing" subject. Todd suggests that we instead shift the focus to passivity and listening as forms of attendance to "dense plots" (2003:121). This can inspire museum teaching to re-think the special potential of exhibitions to appeal to listening in exhibitions.

The exhibition invited to listening when it offered poetic interpretations such as the "kids' bedroom", which could awaken sensibility and vulnerability, and inspire to listening and receiving. Teaching that evokes a deepening of radical responsibility is a practice of working with "exposure to affection, sensibility, a passivity more passive still than any passivity, an irrecuperable time, an unassemblable diachrony of patience, an exposure to expressing, and thus to saying, and thus to giving" (2009:50). The exhibition had the potential to communicate from the holes and margins in ways that were reminiscent of poetry and in its twisted, weird or dreamlike expressions, or murmurs, which both encouraged listening and invited reimaginations of how the current conditions are said. Listening can then be a kind of being-forthe-other as the grounding moment of ethics, where the other and her/his story are welcomed as different from oneself. Listening as a way of welcoming is also the foundational moment for critique, where re-creations of the sense one has of self, others and relations can take place. 
What Lévinas aims at is the discourse before any discourse - the extremely "small" moment of education, the "me voici" (here I am) expressed to the neighbour. This being-forthe-other is the grounding moment of ethics, where the other is welcomed as a radical other, which again is the condition of possibility for critique and re-creation of the sense one has of self, others and relations. The uniqueness of the exhibition in evoking moments of deepening of responsibility rested in its artistic or poetic re-interpretations of experiences of rape and its ability to inspire engagement in being in heterogeneous and unruly proximity, "face-to-face", with what is radically other, without taking away its sting. It is in "fidelity" to this being-touched-by-the-other that the visitor can go on re-thinking the traumatic and difficult cultural history of rape.

When the exhibition was pointing to the discontinuity and ruptures of discourse, it had the opportunity to open educational relations on rape as a matter never to be settled, but as a question continually to be re-opened. The exhibition broke with more traditional ideas of the role of the museum as an ultimate rational agent and knower of things, or as an authority that governs the organising principles of the world. It departed from ideas of the museum as a distanced teacher. And it revealed the crisis of representation in museums i.e. the difficulties involved in displaying the horror of trauma, the taboo or the unspeakable.

Teaching ethics in the museum poses several difficulties. The relation to the other breaks up who I thought I was: it confronts me with serious questions such as "Do I have

the right to live the way I live?" Also, the other is different from me; I simply cannot identify with her/him, but have to care for her/him as different, maybe contradictory to myself and my world view. Furthermore, a relation of responsibility is a heavy burden on my shoulders - the exhibition reveals a responsibility that is mine and mine alone - it depends on me, and as if that was not bad enough, it is a responsibility that can never be fulfilled. I have to live with my inadequacy to fulfill my responsibility, because the other is unruly, beyond my knowledge and control and I can never fully understand her/him. In addition, I cannot rationalise the other, look at her/him from a distracted point of view instead she/he gets under my skin. Finally, experiencing and expressing the other is difficult, because it is as if current expressions do not fit.

My discussion of the exhibition revealed controversial issues as regards victims' responses, privacy, the diversity of visitors and effacements - issues that point to the difficult nature of putting on a display with a topic such as rape. Nevertheless, the exhibition also showed some possible ways for museums to provide a distinct space, different from the media and the school context, for visitors struggling with questions of sensible being in relation to others, and for discussing difficult matters like rape.

The exhibition was not merely based on a calculation of who the visitor was, and not merely an instrument for reaching a predefined goal. It was informal education and space for poetic saying, experience and response. The strength of face-to-face and poetic re-interpretation was that in this case the exhibition presented no ready-made solution or directives for future practice. Also, 
there was no measuring of the learning "outcome". The design of the exhibition broke with a dominant trend of neo-liberal educational discourse, i.e. the idea of education as the site for customerisation, managerialism and performativity, where individuals with measurable skills, ready to enter waged work, are produced.

The museum's intentions - to give visitors a share in responsibility - must be considered in relation to caring for and learning from what is other. This exposes the illusion of selfsufficiency of the visitor as a learning subject. Fundamentally, a question raised by the exhibition is how we can shift focus from "what's in it for me" to being-for-the-other. The question concerns how we can deal with the difficulties of engaging in the life of other people and open up a discourse on a change in the dimensions of caring relationality to other beings different from ourselves. Answering the demand of the stories of others in the exhibition is a way of caring-for-the-other and a possibility of shortcutting the perpetuation of violence.

\section{LITERATURE}

Bal, Mieke 2009/10. "Exhibition as a syntax of the face." Manifesta Journal 9:13-22.

Bonnell, Jennifer \& Simon, Roger I. 2007.

"Difficult exhibitions and intimate encounters." Museum and Society 5(2):65-85.

Butler, Judith 2006. Precarious Life. The Powers of Mourning and Violence. London \& New York: Verso.

Cameron, Fiona \& Kelly, Lynda (eds.) 2010. Hot Topics, Public Culture, Museums. Newcastle upon Tyne: Cambridge Scholars Publishing.

Derrida, Jacques 1997. De l'hospitalité: Anne
Dufourmantelle invite Jacques Derrida à répondre.

Paris: Calman Lévy.

Goodnow, Katherine \& Akman, Haci 2008.

Scandinavian Museums and Cultural Diversity.

New York \& Oxford: Berghahn Books.

Ipsen, Merete 2010. "Det er ikke din skyld."

Kvindemuseets Arbog.

Janes, Robert R. 2007. "Museums, social

responsibility and the future we desire." In

Knell, Simon J., Macleod, Suzanne \& Watson,

Sheila (eds.). Museum Revolutions: How Museums

Change and are Changed. London \& New York:

Routledge.

Janes, Robert R. 2009. Museums in a Troubled World.

Oxon \& New York: Routledge.

Lévinas, Emmanuel 1993. Interview with Michel

Fields, Ina.france (29 June 1993).

http://www.youtube.com/watch?v=Zvnk6moRm

EA\&list $=$ PL30A3FE8A09D01D09\&index $=34$

(accessed 26 October 2012).

Lévinas, Emmanuel 2008/1961. Totality and Infinity.

An Essay on Exteriority. Pittsburgh, PA.:

Duquesne University Press.

Lévinas, Emmanuel 2009/1974. Otherwise than

Being or Beyond Essence. Pittsburgh, PA.:

Duquesne University Press.

Marstine, Janet (ed.) 2011. The Routledge

Companion to Museum Ethics. Redefining Ethics

for the Twenty-First Century Museum. London \&

New York: Routledge.

Sandell, Richard 2003. "Social inclusion, the museum and the dynamics of sectoral change." Museum and Society 1(1):45-62.

Sandell, Richard 2007. Museums, Prejudice and the Reframing of Difference. London \& New York: Routledge.

Sandell, Richard 2011. "On ethics, activism and human rights." In Marstine, Janet (ed.). The

Routledge Companion to Museum Ethics. Redefining Ethics for the Twenty-First Century Museum. London \& New York: Routledge. 
78 Silvén, Eva \& Björklund, Anders (eds.) 2006. Svåra saker. Ting och berättelser som upprör och berörl Difficult Matters. Objects and Narratives that Disturb and Affect. Stockholm: Nordiska Museet. http://www.nordiskamuseet.se/ommuseet/forlaget/svara-saker-ting-och-berattelsersom-uppror-och-beror (accessed October 2013) Simon, Roger I. 2005. The Touch of the Past. Remembrance, Learning, and Ethics. New York: Palgrave Macmillan.

Simon, Roger I. 2006. "The terrible gift: Museums and the possibility of hope without consolation." Museum Management and Curatorship 21(3):187-204.

Todd, Sharon 2003. Learning from the Other. Lévinas, Psychoanalysis, and Ethical Possibilities in Education. New York: State University of New York Press.

Todd, Sharon 2008. "Welcoming and difficult learning: Reading Levinas with Education.” In Egéa-Kuehne, Denise (ed.) Lévinas and Education: At the Intersection of Faith and Reason. London \& New York: Routledge.

Williams, Paul 2011. "Memorial museums and the objectification of suffering." In Marstine, Janet (ed.) The Routledge Companion to Museum Ethics. London \& New York: Routledge.

Witcomb, Andrea 2010. "The politics and poetics of contemporary exhibition making: towards an ethical engagement with the past." In Cameron, Fiona \& Kelly, Linda (eds.) Hot Topics, Public Culture, Museums. Newcastle upon Tyne: Cambridge Scholars Publishing.

Witcomb, Andrea 2013. "Understanding the role of affect in producing critical pedagogy for history museums." Museum Management and Curatorship 28(3):255-271.
*Katrine Tinning, Ph.D. student katrine.tinning@soc.lu.se

Department of Sociology

Division of Education

Lund University

Box 114

SE-221 00 Lund, Sweden 